The Journal of Animal \& Plant Sciences, 31(4): 2021, Page: 954-959

ISSN (print): 1018-7081; ISSN (online): 2309-8694

\title{
MOLECULAR IDENTIFICATION OF CTX GENE OF EXTENDED SPECTRUM BETA- LACTAMASES (ESBL) PRODUCING ESCHERICHIA COLI ON LAYER CHICKEN IN BLITAR, INDONESIA
}

\author{
F. J. Wibisono ${ }^{1}$, B. Sumiarto ${ }^{2}$, T. Untari ${ }^{3}$, M. H. Effendi ${ }^{*}$, D. A. Permatasari ${ }^{4}$ and A. M. Witaningrum ${ }^{4}$ \\ ${ }^{1}$ Doctoral Program in Veterinary Science, ${ }^{2}$ Department of Veterinary Public Health, Faculty of Veterinary Medicine, \\ ${ }^{3}$ Department of Microbiology, Faculty of Veterinary Medicine, Gadjah Mada University, Yogyakarta, Indonesia; \\ ${ }^{4}$ Department of Veterinary Public Health, Faculty of Veterinary Medicine, Airlangga University, Surabaya, Indonesia \\ Corresponding author's email: mheffendi@yahoo.com
}

\begin{abstract}
Escherichia coli is one of the ESBL-producing bacteria responsible for the rise of antibiotic resistance. The most common type of ESBL-encoding gene is cefotaximase (CTX). The aim of study was to identify CTX-encoding gene among Escherichia coli on Layer Chicken in Blitar, Indonesia by using DNA-based techniques. To do this, a total of 130 swab cloacal samples were randomly collected from layer chicken in 4 districts of Blitar. Samples was initially cultured on MacConkey agar and Eosin Methyllen blue agar. Subsequently, the suspected isolates were identified in TSIA test and IMVIC biochemistry test. The method of Confirmation test ESBL-producing Escherichia coli was performed by Double Disc Synergy Test (DDST), and the final characterization of the isolates were conducted using VITEK® 2 Compact. Following that, the identified isolates were exposed to PCR amplification for the presence of CTX gene in ESBL-producing Escherichia coli, followed by the visualization of the amplicons in the electrophoresis. Overall, the results was showed that $80 \%$ of the ESBL-positive isolates contained CTX gene. In conclusion, this report the high frequency of CTX gene in ESBL producing Escherichia coli, and thereby posing a significant threat for the animal and human health.
\end{abstract}

Key words: CTX gene; ESBL; Escherichia coli; Human health; PCR; VITEK®

https://doi.org/10.36899/JAPS.2021.4.0289

Published online December 15, 2020

\section{INTRODUCTION}

Antibiotic resistance is a serious problem worldwide, especially center of layer poultry in Blitar, Indonesia (Wibisono et al., 2020a). Escherichia coli is one of the causes responsible for infection and antibiotic resistance in humans and animals through ESBLmechanism (Paterson and Bonomo, 2005; Amelia et al., 2016). The presence of pathogenic Escherichia coli infections in poultry can adversely affect economy (Wibisono et al., 2018). The usage antibiotics can pose a risk of antibiotic resistance in poultry (Santos et al., 2013). There is restricted data related to the prevalence of antibiotic resistance in developing countries, in particular, Indonesia. Surveillance of antibiotic resistance is needed to monitor the emergence of antibiotic resistance (Kurniawati et al., 2015).

Antibiotic resistance which produced from Escherichia coli is Extended Spectrum $\beta$ - lactamase (ESBL) (Santos et al., 2013; Hammerum et al., 2014). Extended-spectrum beta lactamase is an enzyme that is characterized by the ability to hydrolyze third generation cephalosporins and aztreonam but are inhibited by clavulanic acid (Paterson and Bonomo, 2005; Public Health England, 2014). Exposure large amounts of betalactam antibiotics can induces production and mutation of beta-lactamase type enzyme.
This mutation causes an increase in the enzymatic activity of beta-lactamase so that this enzyme can hydrolyze third generation cephalosporins and aztreonam (Paterson and Bonomo, 2005; Lim et al., 2013). ESBLproducing bacteria can also be resistant to antibiotics from aminoglycoside, fluoroquinolone, tetracycline, chloramphenicol, and sulfamethoxazole-trimethoprim (Brower et al., 2017; Sudarwanto et al., 2017). Extended Spectrum Beta-Lactamase genes are often found in mutated genes, namely cefotaximase (CTX-M), temoneira (TEM) and variable sulfhydryl (SHV). The CTX-M gene in ESBL-producing Escherichia coli is a gene that codes and produces enzymes that can hydrolyze beta lactam rings from third-generation beta lactam antibiotics and cephalosporins (Biutifasari, 2018). The molecular detection is a genotypic confirmatory test to screen the ESBL encoding gene in Escherichia coli bacteria using PCR (Bradford, 2001). The highest prevalence of ESBLproducing bacteria with CTX-M-1 is the most common type of ESBL in poultry (Saliu et al., 2017; Upadhyay et al., 2015; Rao et al., 2014).

ESBL-producing Escherichia coli in India was about $42 \%$ in layer chicken (Brower et al., 2017). In this study, we aimed to identify CTX gene for encoding ESBL producing Escherichia coli from cloacal swabs of layer chicken in Blitar, Indonesia. 


\section{MATERIALS AND METHODS}

Isolation and Identification of Escherichia coli: A total of 130 cloacal swab samples was randomly taken from 4 districts in Blitar. The samples were kept in Amies Swab Viscosa (deltalab, Spain) transport medium at $4{ }^{\circ} \mathrm{C}$, and immediately taken to the laboratory for further analyses (Seni et al., 2016). Isolation of Escherichia coli bacteria using selective media Mac Conkey Agar no. 3 CM0115 (Oxoid, England) and differential media Eosin Methylene Blue Agar CM0069 (Oxoid, England), incubated at of Escherichia coli were identified by biochemical testing of IMVIC (Indol-Motility, Methyl Red, Voges Proskauer, Citrate) and TSIA (Triple Sugar Iron Agar) (Effendi et al., 2018a; Effendi et al., 2019). The identification of Escherichia coli bacteria was confirmed by VITEK $(2$ compact using a VITEK $® 2$ GN card (Biomerieux, 2017).

Confirmation for ESBL producing Escherichia coli: ESBL-producing Escherichia coli bacteria isolated from cloacal swabs of layer chicken were confirmed by the Double Disc Synergy Test (DDST) and VITEK ${ }^{\circledR} 2$ compact. This confirmation test with DDST was conducted to evaluate the presence of inhibitory zones of ESBL activity with clavulanic acid using the Kirby-Bauer disk diffusion method on Mueller-Hinton agar (Merck, Germany). Double Disc Synergy Test uses the antibiotic

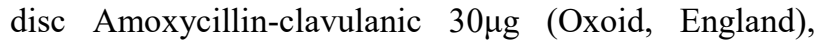

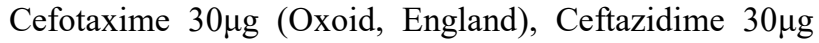
(Becton Dickinson, USA), and Aztreonam 30 $\mu$ g (Oxoid, England).

Culture was incubated at $35-37{ }^{\circ} \mathrm{C}$ for $18-24$ hours (CLSI, 2017; Effendi et al., 2018b). The results of the evaluation after incubation showed that the inhibition zone that appeared in the plate was measured based on CLSI 2017 guidelines (CLSI, 2017) as shown on Figure 2.

The antibiotic sensitivity 102 test of ESBLproducing Escherichia coli bacteria by the DDST was then confirmed by the VITEK $\AA 2$ compact. The bacterial suspension was homogenized and a bacterial turbidity of 0.50 to $0.63 \mathrm{Mc}$ Farland was made using VITEK ${ }^{\circledR} 2$ DensiCHEK (Biomerieux, 2017). Antimicrobial susceptibility and phenotypic detection of ESBL producers using AST N280 cards (bioMérieux, MarcyL'Étoile, France). These results are analyzed automatically by the system and interpreted as sensitive, intermediate, and resistant (Biomerieux, 2017; Brower et al., 2017).

Characterization of CTX gene by Polymerase Chain Reaction (PCR): The ESBL-positive strains were then subjected to molecular screening of CTX-gene. To do this, DNAs were extracted according to the instructions by a mini QIAamp ${ }^{\circledR}$ DNA kit (QIAGEN, Germany). Escherichia coli ATCC 35218 was used as positive control standard for strains of ESBL-producing bacteria, and Escherichia coli ATCC 25922 is used as negative control or non-ESBL-producing bacteria. The primers designed for screening CTX-M gene were used to encode CTX encoding genes using CTX-MA primers (CGCTTTGCGATGTGCAG), CTX-MB (ACCGCGATATCGTTGGT), respectively and the amplicon is 550-bp. The PCR conditions were given as with denaturation temperatures $94^{\circ} \mathrm{C}, 2$ minutes; extended denaturation $94^{\circ} \mathrm{C}, 1$ minute; annealing $54{ }^{\circ} \mathrm{C}, 30$ seconds; extension $72^{\circ} \mathrm{C}$ ), 45 seconds; extended extension $72^{\circ} \mathrm{C}, 5$ minutes, this reaction is carried out for 30 cycles (Ali et al., 2016), and the amplification was carried out by PCR (Blue-Ray Biotech Turbo Cycler, TST-9620). After that, the amplicons were visualized by electrophoresis using $2 \%$ agarose gel (Invitrogen, USA) (Yanestria et al., 2019).

\section{RESULTS}

This study was conducted for the characterization of CTX gene among ESBL-positive E. oli strains isolated from 130 cloacal swab samples in layer poultry. The results were $8.69 \%$ (10) confirmation positive of ESBLproducing Escherichia coli on layer chicken cloacal swab by the Double Disc Synergy Test (DDST), shown on Figure 2. The presence of ESBLs-producing bacteria by double discs synergy test (DDST) to detect ESBL producing bacteria and then confirmed by the automatic VITEK $® 2$ compact and indicated $100 \%$ ESBL producing Escherichia coli as shown in Table 1. For the identification of CTX-encoding gene present in ESBL producing $E$. coli PCR was used (Putra et al, 2019), as shown on Figure 3.

Tabel 1. Data ESBL producing Escherichia coli from cloacal swabs layer chicken in Blitar.

\begin{tabular}{|c|c|c|c|c|c|}
\hline \multirow[b]{2}{*}{$\begin{array}{l}\text { Subdistric } \\
\text { Location }\end{array}$} & \multirow[b]{2}{*}{$\begin{array}{l}\text { Sample } \\
\text { size }\end{array}$} & \multirow[b]{2}{*}{$\begin{array}{c}\text { No of Escherichia } \\
\text { coli isolates }\end{array}$} & \multicolumn{2}{|c|}{ No of ESBL positive strain } & \multirow{2}{*}{$\begin{array}{c}\text { PCR } \\
\begin{array}{c}\text { No of CTX gene positive } \\
\text { strain }\end{array} \\
\end{array}$} \\
\hline & & & DDST & VITEK $^{\circledR} 2$ compact & \\
\hline Ponggok & 40 & 31 & - & - & - \\
\hline Srengat & 45 & 43 & 6 & 6 & 6 \\
\hline Talun & 20 & 18 & 1 & 1 & - \\
\hline$\underset{n}{\text { Kademanga }}$ & 25 & 23 & 3 & 3 & 2 \\
\hline $\begin{array}{l}\text { Total in } \\
\text { Blitar }\end{array}$ & 130 & $\begin{array}{c}115 \\
(115 / 130 ; 88,5 \%)\end{array}$ & $\begin{array}{c}10 \\
(10 / 115 \\
8.69 \%)\end{array}$ & $\begin{array}{c}10 \\
(10 / 10 ; 100 \%)\end{array}$ & $\begin{array}{c}8 \\
(8 / 10 ; 80 \%)\end{array}$ \\
\hline
\end{tabular}




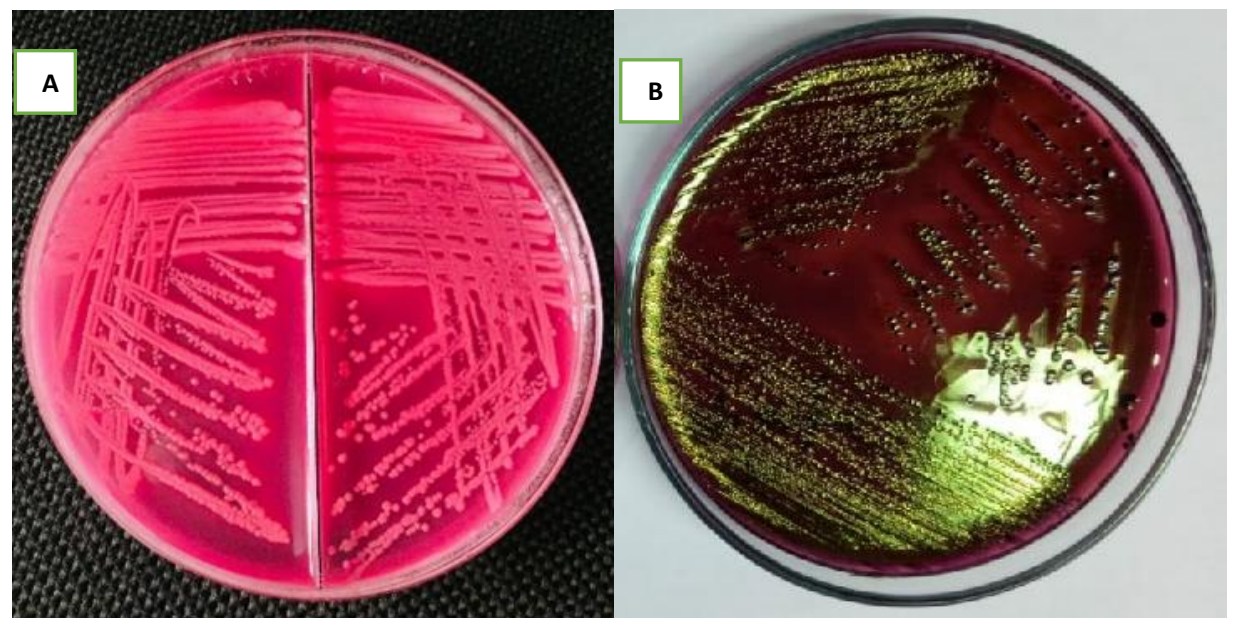

Figure 1. Escherichia coli on MacConkey Agar (A) and on Eosin Methylen Blue Agar (B)

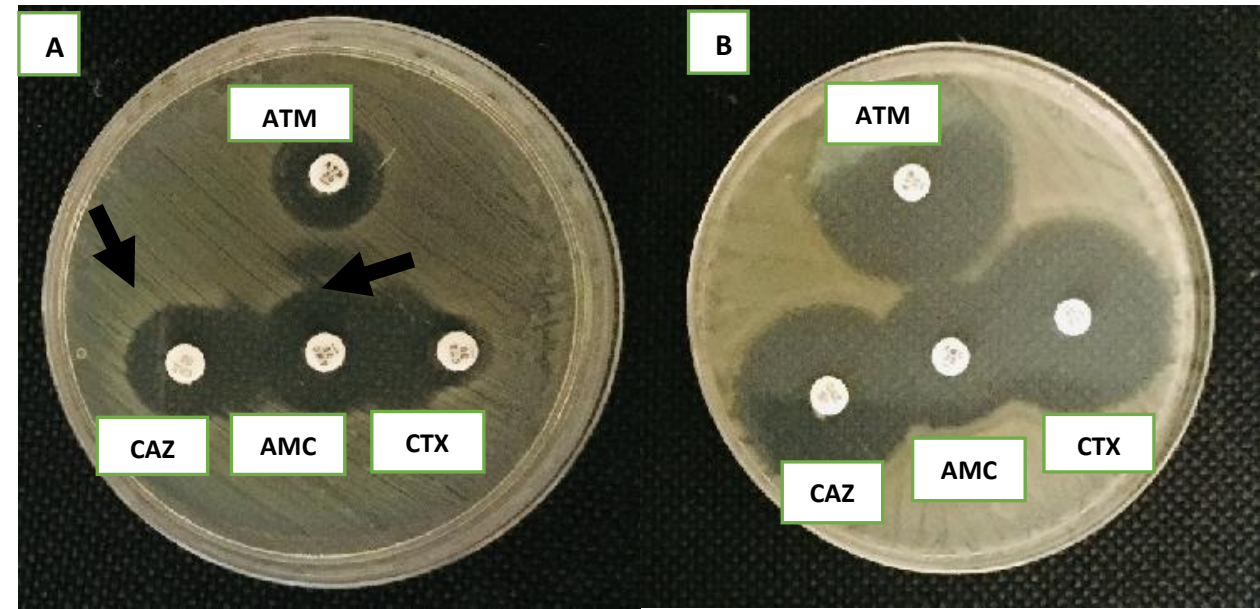

Figure 2. ESBL-producing Escherichia coli confirmation test with Double Disc Synergy Test (DDST) (A) positive result (B) negative result. Note: ATM: Aztreonam, CAZ: Ceftasidime, AMC: Amoxycillin clavulanic, and CTX: Cefotaxime.

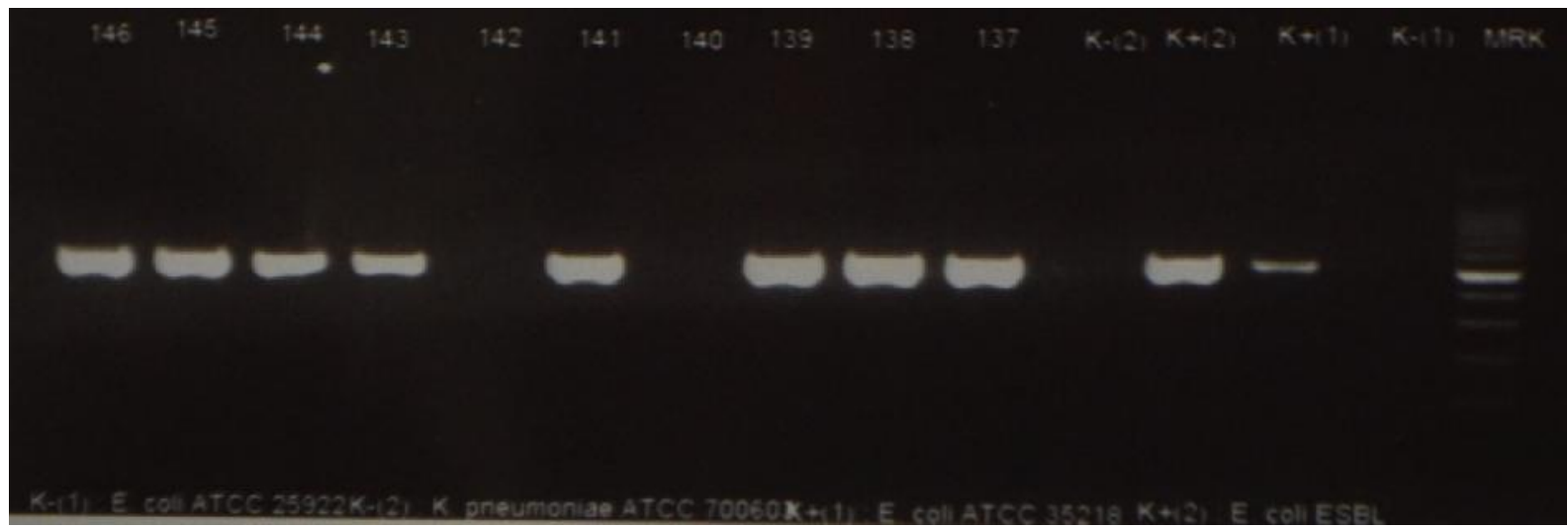

Figure 3. Molecular identification CTX gene of ESBL-producing Escherichia coli by PCR on 550 bp.

Legend: Code sample 140 and 142 there were no CTX gene.

\section{DISCUSSION}

Several other studies have examined the number of $E$. coli isolates that isolated from animal and animal products, showing concordance results between studies as shown on Table 1 (Saliu et al., 2017; Upadhyay et al., 2015; Rao et al., 2014). The relative abundance of the ESBL producing $E$. coli in samples from cattle and dogs has been shown to vary with geographic location (Putra et al., 2019; Kristianingtyas et al., 2020). In this study, 
isolates including ESBL producing E. coli were dominated by encoding CTX gene.

Table 1 showed the spread of ESBL-producing Escherichia coli in 3 districts from 4 districts. Srengat District has 6 samples, one sample from Talun district and Kademangan district was 3 samples from 10 ESBLproducing Escherichia coli samples, while Ponggok district was not found any ESBL producing Escherichia coli.

Cefotaxime synergy with the combination of amoxilin-clavulanate in the form of an expansion inhibition zone between the two discs represent that the bacteria is positive ESBL, synergy of third generation cephalosporins with combination of cephalosporinclavulanic acid in the form of an expansion inhibition zone between the two discs. Positive results on ESBLproducing bacteria confirmed that there was increase in inhibition zone $\geq 5 \mathrm{~mm}$ between diameter of cephalosporin disc and cephalosporin-clavulanate disc combination revealed an ESBL positive (CLSI, 2017). The incidence of ESBL producing Escherichia coli from cloaca swabs on layer chicken was consistent with the incidence of Escherichia coli on slaughterhouses in Bogor by $8.6 \%$ (Sudarwanto et al., 2016), but smaller compared to the incidence of Escherichia coli as ESBL producing Escherichia coli from feces of broiler chickens in Bogor ESBL by 25\% (Masruroh et al., 2016) and the incidence of ESBL producing Escherichia coli in India on layer chicken was around 42\% (Brower et al., 2017).

Molecular identification as shown in Table 1 that 80\% (8/10) samples of ESBL producing Escherichia coli encoding CTX gene. The CTX encoding gene is most commonly found in Escherichia coli. CTX enzymes have hydrophilic ability against cephalosporins, especially cefotaxime, so called CTX (Bradford, 2001). Molecular identification shown in Figure 3 that visualization of the CTX gene fragment band. Electrophoresis results of CTX gene represent samples describing the same fragments as positive controls with a gene length of $550 \mathrm{bp}$ (Ali et al., 2016) as shown on Figure 3.

ESBL bacteria can be identified by detecting the presence of ESBL encoding genes (Bhoomika et al., 2016, Surgers et al., 2019). This research showed that the CTX gene was found in $80 \%$ ESBL samples. Other studies have been carried out mainly ESBL producing Kleibsiella pneumoniae (Hayati et al., 2019). Some investigations show that the dominant genotype found was CTX gene (Zarfel et al., 2014; Ibrahim and Hameed, 2015). This type of ESBL is often seen as single or combination. In this study, the ESBL encoding CTX gene was detected dominance of ESBL producing Escherichia coli samples from layer chicken. The CTX beta lactamase is the most prevalent ESBL type among chicken (96\%) samples (Valentin et al, 2014). In many countries CTX gene is one of the most frequent ESBL types in ESBL-producing bacteria, causing human infections (Alonso et al., 2017), therefore the evidence of CTX gene in this study should be used as reference in controlling the spread of ESBL encoding gene in poultry farms (Wibisono et al., 2020b).

The spreading of genetic elements such as transposons, insertion and integrons in the bacteria cause ESBL genes move quickly from animals to humans or vice versa. Genetic factors can also spread the virus nature of resistance to other bacteria in animals digestive tract. The bacteria then spread from cage to the surrounding environment through facilitated waste by poor hygiene and sanitation, which pollutes land and water around agriculture. ESBL bacteria are also detected in vegetables, soil and surrounding water agriculture and markets (Wu et al., 2016).

The presence of ESBL producing Escherichia coli is threat to the public health and animal health (Kristianingtyas et al., 2020). This condition can occur in limited maintenance options. The steps that can be done is to build supervision program, supervising feed and poultry. Farmers also need to improve biosecurity practice. Garbage and laying chicken manure must be correct managed in an intensive production system, to prevent air, soil and water contamination, as well negative consequences for human health (Thyagarajan et al., 2014).

Conclusion: One hundred and fifteen Escherichia coli samples were isolated from cloacal swabs layer chicken in layer farms Blitar, East Java, Indonesia. Ten E. coli were classified as ESBL bacteria. Through PCR testing, ESBL encoding gene of CTX gene was identified in eight samples. The presence of ESBL encoding gene in bacteria has potential to spread its resistance to the other bacteria in the gastrointestinal tract of layer chickens as well as in the poultry environment.

Conflict of interest: We certify that there is no conflict of interest with any financial, personal, or other relationships with other people or organization related to the material discussed in the manuscript.

Acknowledgements: The authors would like to thank the Rector of Airlangga University for providing HIBAH MANDAT research funds with grant numbers; $371 / \mathrm{UN} 3.14 / \mathrm{LT} / 2019$ on the research title: PENANGGULANGAN VIRULENCE FACTOR ISOLAT GRAM NEGATIVE BACTERIA DARI SUMBER PANGAN ASAL HEWAN DENGAN PENGGUNAAN POLYMERASE CHAIN REACTION. This article is part of the research.

\section{REFERENCES}

Ali, T., S. Rahman, L.Zhang, M.Shahid, S.Zhang, G.Liu, J.Gao, and B. Han (2016). ESBL-Producing Escherichia coli from Cows Suffering Mastitis in China Contain Clinical Class 1 Integrons with 
CTX-M Linked to ISCR1. Front. Cell. Infect. Microbiol. 7:1-11.

Alonso, C.A., M. Zarazaga, R.Ben Sallem, A. Jouini, K.Ben Slama, and C.Torres (2017). Antibiotic resistance in Escherichia coli in husbandry animals. the African perspective. Lett. Appl. Microbiol. 64:318-334.

Amelia, A., A. Nugroho, and P. N. Harijanto. (2016). Diagnosis and Management of Infections Caused by Enterobacteriaceae Producing Extended Spectrum Beta-Lactamase. Acta Medica Indones. The Indones. J. Intern. Med. 48:156-166.

Bhoomika, S. Shakya, A.Patyal, NE.Gade (2016). Occurrence and characteristics of extendedspectrum $\beta$-lactamases producing Escherichia coli in foods of animal origin and human clinical samples in Chhattisgarh, India. Vet. World, 9(9): 996-1000.

Biomerieux. (2017). AST and Resistance Detection, Antibiotic Suceptibility Testing bioMérieux Industry website.

Biutifasari, V. (2018). Extended Spectrum Beta Lactamase (ESBL ). Ocean. Biomed. J. 1:1-6.

Bradford, P. (2001). Extended spectrum betalactamase in the 21 century: characterization, epidemiology, and detection of this important resistant threat. Clin. Microbiol Rev. 14:933-951.

Brower, C. H., S. Mandal, S. Hayer, M. Sran, A. Zehra, S. J. Patel, R. Kaur, L. Chatterjee, S. Mishra, B. R. Das, P. Singh, R. Singh, J. P. S. Gill, and R. Laxminarayan (2017). The prevalence of extended-spectrum beta-lactamase-producing multidrug-resistant Escherichia coli in poultry chickens and variation according to farming practices in Punjab, India. Environ. Health Perspect. 125:1-10.

CLSI. (2017). M100 Performance Standards for Antimicrobial. 27th ed. Clinical and Laboratory Standards Institute, USA.

Effendi, M. H., I. G. Bintari, E. B. Aksoro, and I. P. Hermawan. (2018a). Detection of blaTEM Gene of Klebsiella pneumoniae Isolated from swab of food-producing animals in East Java. Trop. Anim. Sci. J. 41:174-178.

Effendi, M.H, N. Harijani, S.M. Yanestria, and P. Hastutiek. (2018b). Identification of shiga toxinproducing Escherichia coli in raw milk samples from dairy cows in Surabaya, Indonesia. Philippine J Vet Med.55(SI):109-114.

Effendi, M.H., N.Harijani, Budiarto, N.P. Triningtya, W.Tyasningsih, and H. Plumeriastuti (2019). Prevalence of Pathogenic Escherichia Coli Isolated from Subclinical Mastitis in East Java Province, Indonesia. Indian Vet. J., 96 (03) : 22 25
Hammerum, A. M., J. Larsen, V. D. Andersen, C. H. Lester, T. S. S. Skytte, F. Hansen, S. S. Olsen, H. Mordhorst, R. L. Skov, F. M. Aarestrup, and Y. Agerso (2014). Characterization of extendedspectrum $\quad \beta$-lactamase $\quad$ (ESBL)-producing Escherichia coli obtained from Danish pigs, pig farmers and their families from farms with high or no consumption of third- or fourth-generation cephalosporins. J. Antimicrob. Chemother. 69:2650-2657.

Hayati M, A. Indrawati, NLPI Mayasari, I. Istiyaningsih, N. Atikah (2019). Molecular detection of extended-spectrum $\quad \beta$-lactamase-producing Klebsiella pneumoniae isolates of chicken origin from East Java, Indonesia. Vet. World, 12(4): 578-583.

Ibrahim, I.A.J. and T.A.K Hameed (2015). Isolation, Characterization and antimicrobial resistance patterns of lactose-fermenter Enterobacteriaceae isolates from clinical and environmental samples. J. Med. Microbiol., 5 : 169-176.

Kristianingtyas, L., M. H.Effendi, W.Tyasningsih, and F. Kurniawan (2020). Genetic Identification of blactx-M Gene and blatem Gene on Extended Spectrum Beta Lactamase (ESBL) Producing Escherichia Coli from Dogs. Indian Vet. J. 97 (01) : 17 - 21

Kurniawati, A. F., P. Satyabakti, and N. Arbianti (2015). Differences in Risk of Multidrug Resistance Organisms (MDROS) According to Hand Hygiene Risk Factors and Compliance. J. Berk. Epidemiol. 3:277-289.

Lim, C. L. L., W. Lee, A. L. C. Lee, L. T. T. Liew, S. C. Nah, C. N. Wan, M. P. Chlebicki, and A. L. H. Kwa. (2013). Evaluation of ertapenem use with impact assessment on extended-spectrum betalactamases (ESBL) production and gramnegative resistance in Singapore general hospital (SGH). BMC Infect. Dis. 13:1-10.

Masruroh, C. A., M. B. Sudarwanto, and H. Latif. (2016). Incidence Rate of Escherichia coli Producing Extended Spectrum B-Lactamase Isolated from Broiler Faeces in Bogor City. J. Sain Vet. 34:4249.

Paterson, D. L., and R. A. Bonomo. (2005). Extended Spectrum Beta-Lactamases : a Clinical Update. Clin. Microbiol. Rev. 18:657-686.

Public Health England. 2014. Extended-spectrum betalactamases (ESBLs)_ guidance, data, analysis GOV.

Putra, A. R. S., M.H. Effendi, S. Koesdarto, and W. Tyasningsih (2019). Molecular Identification of Extended Spectrum Beta-Lactamase (ESBL) Producing Escherichia coli Isolated From Dairy Cows in East Java Province, Indonesia. Indian Vet. J. 96 (10) : $26-30$. 
Rao L, L. Lv, Z. Zeng, S. Chen, D. He, X. Chen, C. Wu, Y. Wang, T. Yang, P. Wu, Y. Liu, and JH Liu. (2014) Increasing prevalence of extendedspectrum cephalosporin-resistant Escherichia coli in food animals and the diversity of CTX-M genotypes during 2003-2012. Vet. Microbiol. 172:534-541.

Saliu, E. M., W. Vahjen, and J. Zentek. (2017). Types and prevalence of extended-spectrum beta-lactamase producing Enterobacteriaceae in poultry. Anim. Heal. Res. Rev. 18:46-57.

Santos, L. L., R. A Dos,. P. Moura, A. P. AguilarRamires,. De Castro, and N. Lincopan. (2013). Current status of extended-spectrum $\beta$-lactamase ( ESBL ) -producing Enterobacteriaceae in animals. Microb. Pathog. Strateg. Combat. them: Sci. Technol. Educ. 1600-07.

Seni, J., L. Falgenhauer, N. Simeo, M. M. Mirambo, C. Imirzalioglu, M. Matee, M. Rweyemamu, T. Chakraborty, and S. E. Mshana (2016). Multiple ESBL-producing Escherichia coli sequence types carrying quinolone and aminoglycoside resistance genes circulating in companion and domestic farm animals in Mwanza, Tanzania, harbor commonly occurring plasmids. Front. Microbiol. 7:1-8.

Sudarwanto, M. B., D. W. Lukman, H. Latif, H. Pisestyani, E. Sukmawinata, Ö. Akineden, and E. Usleber. (2016). CTX-M producing Escherichia coli isolated from cattle feces in Bogor slaughterhouse, Indonesia. Asian Pac. J. Trop. Biomed. 6:605-608.

Sudarwanto, M. B., D. W. Lukman, T. Purnawarman, H. Latif, H. Pisestyani, and E. Sukmawinata. (2017). Multidrug resistance extended spectrum $\beta$ lactamase and AmpC producing Escherichia coli isolated from the environment of Bogor Slaughterhouse, Indonesia. Asian Pac. J. Trop. Biomed. 7:708-711.

Surgers L, P. Boersma, PM. Girard, A. Homor, D. Geneste, G. Arlet, D. Decré, and A. Boyd (2019). Molecular epidemiology of ESBL-producing $E$. coli and $K$. pneumoniae: establishing virulence clusters. Infection and Drug Resistance, 12: 119127

Thyagarajan, D., M. Barathi, and R. Sakthivadivu, (2014) Risk mitigation of poultry industry pollutants and waste for environmental safety. Glob. J. Sci. Front. Res. Agric. Vet., 14(1): 1-10.
Upadhyay, S., A. Hussain, S.Mishra, A.P. Maurya, A.Bhattacharjee, and S.R Joshi (2015) Genetic Environment of Plasmid Mediated CTX-M-15 Extended Spectrum Beta-Lactamases from Clinical and Food Borne Bacteria in NorthEastern India. PloS ONE 10: e0138056.

Valentin, L., H Sharp, K.Hille, U. Seibt, J. Fischer, and Y. Pfeifer (2014). Subgrouping of ESBL-producing Escherichia coli from animal and human sources: an approach to quantify the distribution of ESBL types between different reservoirs. Int. J. Med. Microbiol. 304, 805-816.

Wibisono, F. J, B. Sumiarto, and TA. Kusumastuti (2018). Economic losses estimation of pathogenic Escherichia coli infection in Indonesian Poultry Farming. Bul. Peternak. 42:341-346.

Wibisono, F.J., B.Sumiarto, T.Untari, M.H. Effendi, D.A. Permatasari, and A.M. Witaningrum. (2020a). The Presence Of Extended Spectrum BetaLactamase (ESBL) Producing Escherichia Coli On Layer Chicken Farms In Blitar Area, Indonesia. Biodiversitas, 21 (6): 2667-2671

Wibisono, F.J., B.Sumiarto, T.Untari, M.H. Effendi, D.A. Permatasari, and A.M. Witaningrum. (2020b). CTX Gene of Extended Spectrum BetaLactamase (ESBL) Producing Escherichia coli on Broilers in Blitar, Indonesia. Sys Rev Pharm, 11(7): 396-403.

Wu, H., M. Wang, Y Liu,., X. Wang, Y. Wang, J. Lu, and H. Xu (2016). Data on the phylogenetic typing, integrin gene cassette array analysis, multi-drug resistance analysis and correlation between antimicrobial resistance determinants in Klebsiella strains. Data Brief, 8 : 1289-1294.

Yanestria, S.M., R.P. Rahmaniar, F.J. Wibisono, and M.H. Effendi, (2019). Detection of invA gene of Salmonella from milkfish (Chanos chanos) at Sidoarjo wet fish market, Indonesia, using polymerase chain reaction technique. Vet.World, 12(1): 170-175.

Zarfel, G., H. Galler, J., Luxner, C. Petternel, , F.F. Reinthaler, D. Haas, C. Kittinger, A.J. Grisold, P. Pless, and G. Feierl, (2014). Multiresistant bacterial isolated from chicken meat in Austria. Int. J. Environ. Res. Public Health, 11(12): 12582-12593. 